\title{
9. ディスポーザブル金属医療用具の放射線隇菌
}

放射線滅菌に打ける滅菌線量決定のための指 標菌の D值の算出は，当該医療用具に指標菌を 塗布をたは，添付したものを試料として照射・処 理する方法が常法とされている，一方， ${ }^{60} \mathrm{Co}$ 線 を金属に当てるとての表面から二次電子がとび 出し，物理化学作用を発揮することがタミカル ドシメータ等を用いた実験で明らかにされてい る.そこでこれら二次電子の殺菌効果への影響 を知るため, 指標菌塗布試料を金属製品の表面 飞添付して照射し，D值の変動の有無について 調ベた。

\section{実験方法}

指標菌としては，B. pumilus ATCC 27142 を用いた，指標菌を添付する金属製品としては 市販のステンレス製替刃メス，採血用ランセッ 卜および類似物質として厚さ $0.5,1,2 \mathrm{~mm}$ の ステンレス板, 厚さ $1 \mathrm{~mm}$ のアルミニウム板を 用いた。

照射用試料は，常法により精製した指標菌胞 子水懸濁液の一定量を; 咕ラス繊維製沪紙（東 洋 GA 100）に塗布・乾燥したバイオロジカル インジケータ（以下 BI と略記する）を上記の 金属物質に密着させてピールパックに封入して 作成した。

放射線の照射は，都立アイソトープ総合研究 所の $5 \mathrm{k} \mathrm{Ci}{ }^{60} \mathrm{Co} r$ 線照射装置を用い, $0.1 \sim 1.0$ $\times 10^{6} \mathrm{R}$ の範囲で， $\mathrm{BI}$ 側または金属側から照射 した.

生残菌数の測定は， BI を径 $5 \mathrm{~mm}$ のガラス ビーズ入り試験管（径 $20 \mathrm{~mm}$ ) 飞少量の滅菌水 とともに入れ，オートミキサーで30〜60秒間処 理して汇紙を均一に分散させたものを試料液と

* 日本アイソトープ協会

*2 都立アイソトープ総合研究所



図1 ステンレス板 (ST) に添付して照射した B. pumilus ATCC 27142 (BI) の生残曲線

し, Trypticase soy agar (BBL) を用いた平 板混釈法により行った。培養は $37^{\circ} \mathrm{C} 48$ 時間と した.

結 果

BI をステンレス板に添付し，BI 側から照射 した場合の $\mathrm{D}$ 值は，図1飞示すよ 5 に BI 単独 の場合より小さくなったが，ステンレス板側か ら照射した場合の D 值は，BI 単独の場合より 大きくなった。

次に金属板の厚みの影響を調べるため，ステ ンレス板の厚みを $0.5,1$ および $2 \mathrm{~mm}$ 変え てD值を算出したが，いずれもほぼ同じ值とな り厚みの影響は認められなかった。

$\mathrm{BI}$ 側から照射したとき，D值が小さくなる のは金属表面で反射した $\gamma$ 線あるいは $\gamma$ 線の照 射によって表面から出た二次電子などの殺菌効 果への影響が考えられる。そこで BI とステン レス板の間にプラスチック板（厚さ $2 \mathrm{~mm}$ ) を はさみ，BI 側から照射したところ，図 2 飞示す 


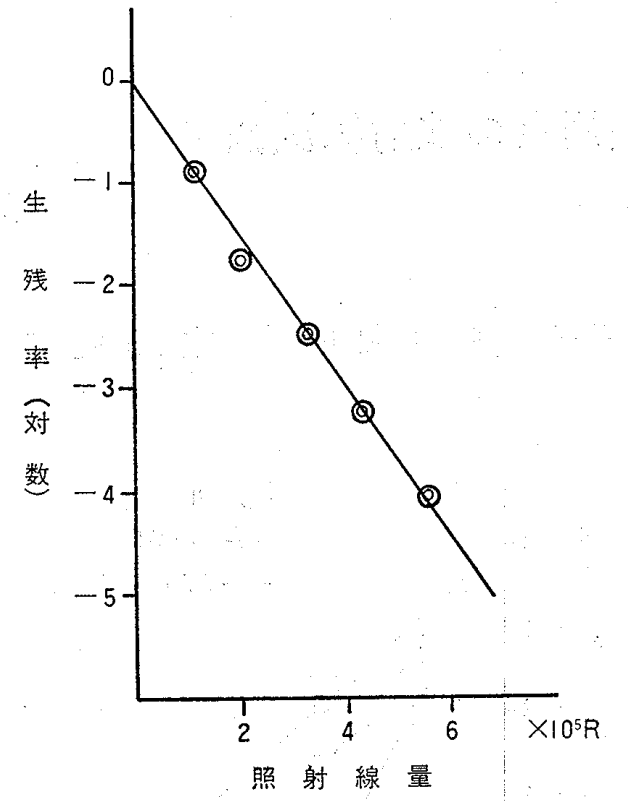

図 2 B.pumilus ATCC 27142 (BI) とステン レス板 (ST)の間にプラスチック板 $(\mathrm{P})$ をはさ んで照射した場合の生残曲線

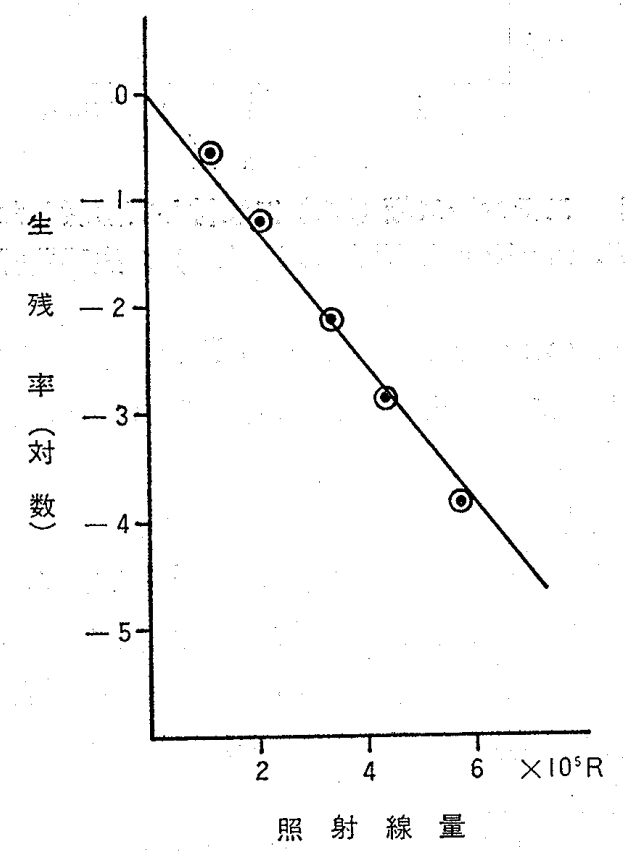

図 3 ステンレス板 (ST) にはさんで照射した

B. pumilus ATCC 27142 (BI) の生残曲線

ように D 值は $\mathrm{BI}$ 単独の場合と同しとなった。

BI をステンレス板の間にはさんで照射した 場合も図 3 に示すように，BI 単独の場合と同 ビような生残曲線となった。

ステンレス板のかわりに，替刃メス（厚さ $0.35 \mathrm{~mm}$ ）を用いた場合は，図 4 飞示すように ステンレス板と同様の結果となった。すなわち

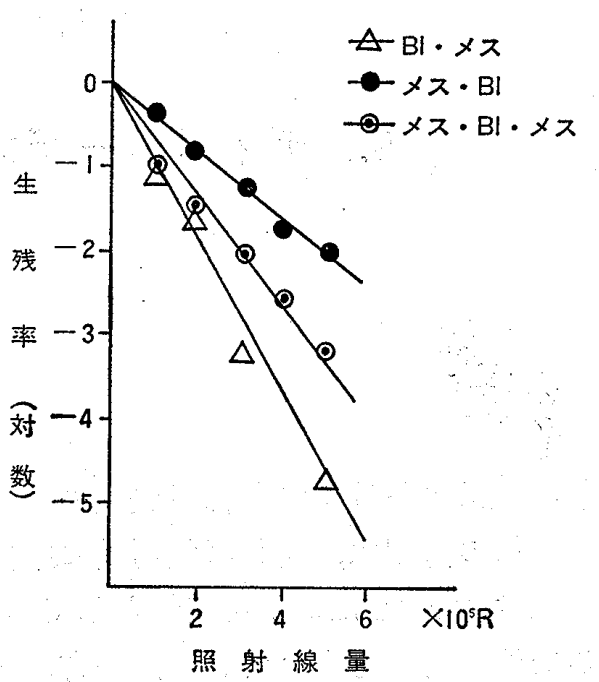

図 4 替刃メスに添付して照射した B. pumilus ATCC 27142 (BI) の生残曲線

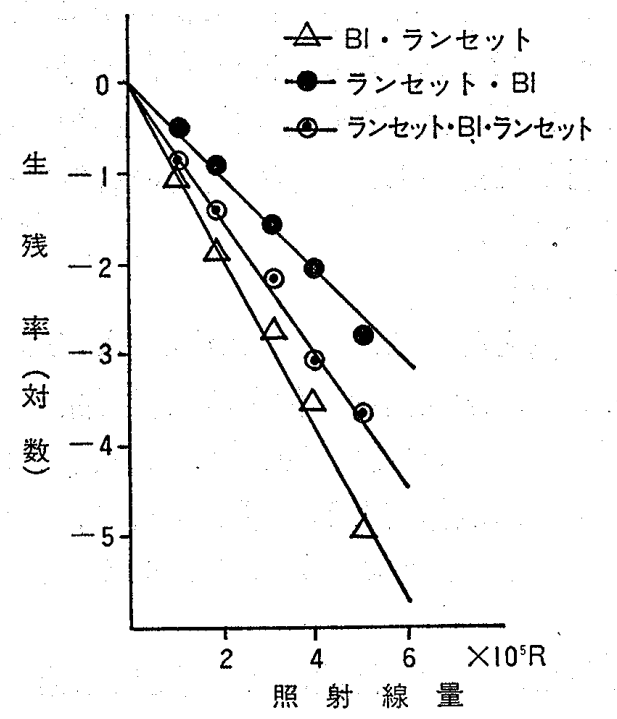

図 5 ランセットに添付して照射したB.pumilus ATCC 27142 (BI) の生残曲線

BI そメスに添付し BI 側から照射した場合，D 值は BI 単独の場合より小さく, メス側から照 射した場合は大きくなった。メスとメスの間に BI をはさんで照射した場合は，BI 単独照射の D值とほぼ等しくなった。これはランセットの 場合も同様の傾向が認められた。（図 5 )

次に材質をアルミニウムに变えて同様の実験 を行ったが，D值に差はあるが傾向としては図 6 に示すようにステンレス板の場合と同じであ った.

\section{考 察}

$\mathrm{BI}$ をステンレス板, 替妇メスおよびランセッ トに添付して BI 側から照射した場合，D值が 
医器学 Vol. 51, Suppl. (1981)

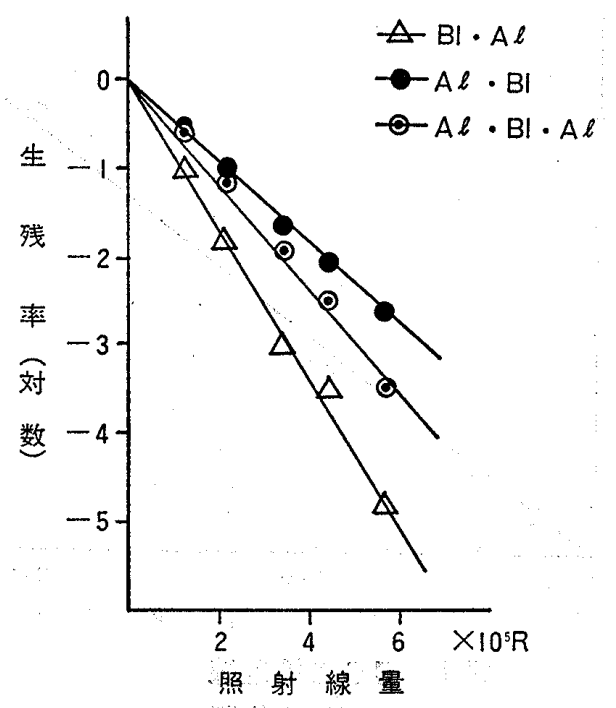

図 6 アルミニウム板 $(\mathrm{A} l)$ に添付して照射した B. pumilus ATCC 27142 (BI) の生残曲線

減少した。この現象はBI とステンレスの間に プラスチック板をはさむことによってステンレ ス板の存在による影響が消失することから，反 射したケ線ではなく金属表面から出た透過力の 弱い二次電子の効果と考えられた， BI を金属 に添付し，金属側から照射した場合，D值が増
大したのはステンレス板の遮へい効果によると 考えられる。亦たランセットに添付した B.pumilus のD值の值がメスに添付したものと異な ったのは，ランセットの表面に凹凹があり，BI が密着しなかったための影響と考㝋られる。

\section{結 語}

金属製品に BI を添付して照射した場合の指 標菌の放射線抵抗性を調べ，

（1）線源側に BI を添付した時には，D值は減 少したが， BI と金属の間にプラスチック板を はさんで照射した場合には，金属の影響が消失 した.

（2）金属側から照射した場合には，D值は增大 した。

（3）金属板の間に BI をはさんだ場合は，BI 単 独の場合と注ぼ等しい值となった。

（4）以上の結果から，金属製品の放射線滅菌条 件を決定するためにD值を算出する場合には， 線源に対して指標菌の添付位置を十分に考慮し て実験を行う必要がある。 などの点を明らかにした。

\section{0. ガスクロマトグラフィによる人工腎臓血液回 路の残留エチレンオキサイドの定量

\section{I 目 的}

エチレンオキサイド (EO) は殺菌力が強く, 低温滅菌に応用し得るため, ディスポーザブル 医療用具などの滅菌に用いられている。しかし EO は滅菌作業従事者がこれに暴露されたとき は皮膚および粘膜に障害を起こすため, 労衝衛 生法により作業環境中 $50 \mathrm{ppm}$ 以下に規制さ机 ている ${ }^{1,2\rangle}$.またEOは軟質塩化ビニル樹脂に吸 着されやすく残留したとき血液に接触して溶血
目黒賢二* 前田悦子* 上野文敏*

* 栄研器材(侏開発部

作用等の毒性を起こすことが知られている ${ }^{3 n 5)}$. FDA は, 1978.6.23 付の Federal Register で, GMP の規制の中で残留規制案を提示した。す なわ方医薬品および医療器具の保存期間中の残 留量の規制の適用を医療用具につひても，在庫 期間中に品質が変わってはならないという GM $\mathrm{P}$ 規制を適用することにしている。そこで演者 らは滅菌物の保存環境温度条件の違いによる残 留 $\mathrm{EO}$ の減少について2，3の知見を得たので 報告する。

\section{II 実験方法}

